Article

\title{
Biopsychosocial Characteristics of Accused Child Sex Offenders in the Intrafamilial and Extrafamilial Contexts
}

\author{
Lucilene Paiva da Costa* \\ Orcid.org/0000-0002-1640-0530 \\ Carlos Joaquim Barbosa da Rocha \\ Orcid.org/0000-0002-2378-4413 \\ Lília Iêda Chaves Cavalcante \\ Orcid.org/0000-0003-3154-065
}

Universidade Federal do Pará, Belém, PA, Brasil

\begin{abstract}
Child sex offenders have been receiving increasing attention from human development researchers. The present study analyzed the data from 206 criminal prosecutions in courts specializing in crimes against children and adolescents, between 2012 and 2014. We employed a Biopsychosocial Characterization Form to record the data extracted from the court documents. For data analysis, we used descriptive statistics and the Logistic Regression Model, indicating the Odds Ratio (OR) and the likelihood of sexual abuse for each context. Child sexual abuse within the extrafamilial context predominated (53\%), with acquaintances of the victims' families being the most frequent offenders (81\%). Within the intrafamilial context, parents and stepparents predominated (53\%). We also discovered that accused offenders over the age of 30 displayed two times more likelihood of belonging to the victim's intrafamilial context than those under the age of $30(\mathrm{OR}=2.949)$. Further studies will be able to refine the preliminary findings of these analyses.
\end{abstract}

Keywords: Sexual violence, children and adolescents, biopsychosocial characteristics.

\section{Características Biopsicossociais entre Acusados de Agressão Sexual contra Crianças/Adolescentes em Contextos Intra e Extrafamiliar}

\section{Resumo}

Autores de agressão sexual a crianças e adolescentes têm recebido maior atenção por parte dos estudiosos do desenvolvimento humano. Este estudo analisou dados de 206 processos de uma vara especializada em crimes contra a criança e o adolescente, entre 2012 e 2014. O Formulário de Caracterização Biopsicossocial tornou possível o registro dos dados extraídos desses documentos. Para análise dos da-

* Mailing address: Travessa Padre Eutíquio, no 1922, Apto. 2300, Edifício Piazza Venezia, Batista Campos, Belém, PA, Brasil 66033-000. Fone: (91) 98221-1791. E-mail: lucilenepc75@gmail.com

This article originated from the first author's masters dissertation, entitled Biopsychosocial Characteristics of Child Sex Offenders in the Intrafamilial and Extrafamilial Contexts, which was defended in the Federal University of Pará (UFPA) Graduate Program in Behavioral Theory and Research in 2015.

Support: Tribunal de justiça do estado do Pará; Conselho Nacional de Desenvolvimento Científico e Tecnológico. 
dos, utilizou-se estatística descritiva e o Modelo de Regressão Logística, indicando a Razão de Chance (OR) e a probabilidade da agressão sexual por contexto. Predominaram as agressões ocorridas no contexto extrafamiliar (53\%), sendo os conhecidos das famílias das vítimas os acusados mais frequentes (81\%). Já no contexto intrafamiliar, destacam-se os pais ou padrastos (53\%). Verificou-se ainda que pessoas acusadas acima dos 30 anos possuíam aproximadamente duas vezes mais chance de pertencer ao contexto intrafamiliar da vítima quando comparado aos com idade abaixo de 30 anos $(\mathrm{OR}=2,949)$. Novos estudos podem refinar as conclusões preliminares destas análises.

Palavras-chave: Agressão sexual, crianças e adolescentes, características biopsicossociais.

\section{Características Biopsicosociales entre en los Acusados de Agresión Sexual Contra los Niños / Adolescentes en el Contexto Intra y Extra Familiar}

\section{Resumen}

Autores de violencia sexual contra los niños y los adolescentes han recibido mucha atención de los expertos del desarrollo humano. La presente investigación analizó los datos de 206 procesos de un distrito judicial especializado en ese tipo de crímenes entre 2012 y 2014. El Formulario de Caracterización Biopsicosocial posibilitó el registro de los datos extraídos de esos documentos. Para el análisis de los datos, se utilizó la estadística descriptiva y el Modelo de Regresión Logística, indicando la Razón de Chance (OR) y la probabilidad de la violencia sexual por contexto. Predominaron las agresiones ocurridas en el contexto extra familiar (53\%), en el que los conocidos de las familias de las víctimas son los acusados más frecuentes (81\%). Ya en el contexto intrafamiliar, se destacan los padres o padrastros (53\%). Se observó también que las personas acusadas que tienen más de 30 años de edad poseían aproximadamente dos veces más chance de pertenecer al contexto intrafamiliar de la víctima cuando se compara con las personas que tienen menos de 30 años $(\mathrm{OR}=2,949)$. Nuevas investigaciones pueden refinar las conclusiones preliminares de este análisis.

Palabras clave: Violencia sexual, niños y adolescentes, características biopsicosociales.

Sexual abuse of minors is a grave social problem with numerous repercussions. This form of violence occurs in both the intrafamilial and extrafamilial contexts. In the former, sexual violence occurs predominantly within the home environment - in the residence of either the victim or the offender - and is usually committed by a close relative. In the latter, sexual violence mostly occurs away from the victims' homes, committed by people who are unrelated to the victims (Alves, Santos, Oliveira, \& Ramos, 2013).

A study conducted by Jesus and Moreira (2015) revealed that, within the intrafamilial context, besides having spouses and children, most of the alleged perpetrators of sexual violence against children and adolescents also held jobs and engaged in various professional activities. Research performed by Pincolini, Hutz, and Laskoski (2012) concluded that making the perpetrated violence known to the public entails numerous consequences for the individuals involved, such as the dissolution of socio-affective bonds and of families, since the violence frequently occurs within the domestic environment and involves members of the same family. Along these lines, several studies demonstrate that the offender can be removed from the shared residence or punished by imprisonment. There are cases in which, in order to protect the victims, courts specializing in crimes against children can decide to assign them to adoptive institutions or foster families (Habigzang, Azevedo, Koller, \& Machado, 2006; Habigzang, Koller, Azevedo, \& Machado, 2005).

Within the intrafamilial context, sexual violence has been associated with the incidence of longstanding, frequent acts whose psychological 
consequences can be even more disturbing in such situations because they entail guilt feelings sustained by the victims (Martins \& Jorge, 2010; Pincolini \& Hutz, 2014). Other studies reveal that extrafamilial sexual abuse can occur in private areas (e.g., the residence or vehicle of the sex offender or of a third party) and public areas (public highways, empty lots, recreational areas) as well as in institutions (educational establishments and places dedicated to group meetings and other activities). With respect to the victims, the social and psychological consequences can be social isolation, psychological traumas, lack of self-esteem, and depression (Santos \& Ippolito, 2011).

In both contexts, the violence is associated with the behavior of adult caregivers who take advantage of the disparity of their age, power, authority or strength to impose their desires and interests (Cerqueira \& Coelho, 2014; Guimarães \& Villela, 2011). For this reason, it is important to conduct research that can identify and list the biopsychosocial characteristics of sexual offenders within both contexts in which this form of violence has been studied. This is an interesting strategy when seeking to comprehend deviant sexual behavior in a contextualized manner.

Within the Brazilian context, literature concerning sex offenders is still scarce, which could reflect the amount and quality of public policies and measures focused on such offenders, principally with respect to preventing recurrence (Lodetti, 2010). Nonetheless, several Brazilian studies have revealed an increasing interest in this subject (Chaves \& Costa, 2012; Esber, 2009; Pincolini et al., 2012; Pincolini \& Hutz, 2014; Santos et al., 2015). Even so, it is important to remember that the expansion of research on child sexual abuse is full of difficulties obstructing the acquisition of the data necessary to achieve such expansion, principally with respect to the perpetrators of sexual violence, for access to this group of offenders is still considered difficult. The literature reveals that most of the research concerning child sex offenders involves prisoners who are under the responsibility of the courts of the jurisdiction in which such offenders reside or perpetrated the sexual abuse (Vieira, Grossi, \& Gasparotto, 2014).
A feasible alternative with respect to surveys of prison populations is documentary research, which permits collecting sex offender data from criminal prosecutions, police investigations and public health reports, among others. Documentary research conducted in Brazil deals mainly with the sociodemographic characteristics of the victims and perpetrators of sexual violence (Hohendorff, Costa, Habigzang, \& Koller, 2014; Pincolini et al., 2012; Silva, Brito, Araújo, \& Abath, 2013).

In order to study the biopsychosocial characteristics of sexual offenders, research based on documental sources has been successfully performed because, in such research, data is usually collected from documents employed in police investigations and criminal prosecutions, medical records and other types of records that can provide complete data as to the sexual abuse committed. Taking court cases as a data source, surveys have been conducted as to the sociodemographic characteristics of offenders and victims, and the context in which the crimes occurred.

As an example of this type of research, we cite a descriptive documental study that was conducted by Hohendorff et al. (2014), concerning forms of sexual violence committed against boys. Between 2009 and 2011, 239 reports of sexual violence filed with the Coordenadoria Geral de Vigilância em Saúde (Health Inspector General's Office) were analyzed; the results revealed that this type of violence was more common in the intrafamilial context (57.9\%) than in the extrafamilial context $(41.3 \%)$. Within the intrafamilial context, the place most frequently cited as being the location at which such violence occurred was the victim's residence (78.7\%); within in the extrafamilial context, the most common locations were public areas such as institutional care units $(6.5 \%)$, public roads $(5.7 \%)$ and schools (5.2\%). In the study, those who committed sexual violence against boys were identified as heterosexuals, and the great majority of them were men (93\%).

A study conducted by Silva et al. (2013), concerning domestic, sexual and other forms of violence reported in 2012 to the Brazilian Case Registry Database (SINAN) in Recife, identi- 
fied 3,199 cases. According to the study, the victims were principally women (67.3\%), 33.6\% of whom belonged to the 0-to-9-year age group, $23.9 \%$ of the 3,199 reported cases referred to sexual assaults, identifying the principal offender as a relative of the victim in $69.3 \%$ of the assaults and as a stranger in $30.7 \%$. In contrast, a study by Baía, Veloso, Habigzang, Dell'Aglio and Magalhães (2015), comparing the patterns of detection and disclosure of sexual abuse in the Brazilian state of Rio Grande do Sul to those of the state of Pará, revealed that, in the former, sexual assaults within the intrafamilial context were the most common (62.41\%); while in the latter, sexual violence within the extrafamilial context predominated (67.7\%).

Documentary research conducted by Pincolini et al. (2012) between 1996 and 2007, concerning 229 criminal cases tried in the $1 \mathrm{st}$ and 2nd District Juvenile Courts specializing in the protection of minors in Porto Alegre, Brazil, analyzed the sociodemographic characteristics of victims and perpetrators of sexual assaults and the contexts in which such violence occurred. The study revealed that $96 \%$ of those who committed this type of assault were men and $53 \%$ were relatives or acquaintances of the victim.

By way of the data extracted from case files, it is possible to identify the characteristics of the behavioral patterns of those who commit sexual assaults against children/adolescents within diverse contexts. Along these lines, the present study aims to analyze and compare the biopsychosocial traits of persons accused of committing sexual violence against minors inintrafamilial and extrafamilial contexts, examining criminal trials conducted between 2012 and 2014 in the Belém District Court Juvenile Division specializing in crimes against minors. We aimed to discover the general traits that characterize the population under examination and their implications with respect to the study of this phenomenon, highlighting the connection between the biopsychosocial characteristics of the subjects involved and the contexts in which the violence occurred.

\section{Method}

\section{Definition}

The present research is a descriptive, documental study of an exploratory nature, involving a quantitative approach.

\section{Sample}

The present study involved checking the secondary data of 250 cases triedin the courts of three municipalities of the state of Pará (Abaetetuba, Belém and Parauapebas) between 2012 and 2014. This period was selected because it featured a significant number of cases in the Litigation Management System (also referred to as the LIBRA System) of the State of Pará Court of Justice (TJPA, in Portuguese). For the present study, we chose to examine the data from the city of Belém exclusively because, compared to the other two cities surveyed, Belém displayed the largest number of litigations (206), representing $82 \%$ of the total (250).

\section{Instrument}

Prepared by our research team and based on a study by Habigzang et al. (2005), a Biopsychosocial Characterization Form (BCF) was employed to collect the data for the present study. It enabled our team both to gather information as to the biopsychosocial traits of accused child sex offenders and to record information regarding their victims and the sexual assaults of which they were accused. The data was classified according to the context in which the assault occurred: intrafamilial or extrafamilial.

Each BCF item was divided into sub-items, namely the following: information identifying the court case (case number, date the proceedings commenced, date of the first sexual assault, date of the police report, length of the proceedings); sociodemographic and procedural data of the accused offenders and the victims (date of birth, sex, race, religion, marital status, children, education, relationship to the victim, classification of the crime, procedural status of the accused, prior convictions); and information 
concerning the characteristics of the sexual violence (location of the crime scene, intrafamilial vs. extrafamilial context, number of incidents of sexual violence).

\section{Data Collection Procedures}

A five-person team collected the data by way of a meticulous analysis of the court cases tried between 2012 and 2014 in the Belém District Court Juvenile Division specializing in crimes against minors. We accessed the cases through the TJPA's LIBRA System. After reading the documents in the case files, the data we obtained was recorded on the BCF.

\section{Data Analysis Procedure}

At first, the collected data was stored on a Microsoft Excel spreadsheet; it was then transferred to an IBMSPSS Statistics software package (version 20) according to the categories that make up the BCF, the instrument employed for data collection. These categories correspond to the two contexts in which the sexual assaults were committed: intrafamilial and extrafamilial.

Next, we associated the analyzed variables with the biopsychosocial traits of both those accused of committing sexual assaults and their victims, and with the characteristics of this form of violence. We employed a multiple binary logistic regression model in the statistical analysis, considering the context of the sexual assault a dependent variable.

The multiple logistic regression model was estimated using the non-automatic Stepwise Forward variable selection method. Each variable's inclusion in the model was checked via the likelihood ratio test and Akaike's criterion (AIC). The odds ratios (ORs) and their respective confidence intervals were of the order of $95 \%$. A $5 \%$ significance level was adopted for all of the analyses, which were conducted using the IBM SPSS Statistics software package (version 20.0 for Windows).

\section{Ethical Procedures}

The present study was approved by the Human Research Ethics Committee of the
Federal University of Pará Tropical Medicine Center (case no. 650,210; April 2014), in compliance with National Health Council/ Health Ministry resolution no. 466 (December 12, 2012), which governs scientific research involving human beings.

\section{Results}

In 99 of the 206 cases examined (48.1\%), accused child sex offenders belonged to the intrafamilial context; in 107 cases $(51.9 \%)$, to the extrafamilial context. No significant statistical difference was observed in the distribution of cases between contexts $\left(X^{2}=0.311 ; d f=1 ; p=\right.$ .57). With regard to the characteristics of the sexual violence in the two contexts under study, and focusing specifically on the location and number of violent incidents, the results for the intrafamilial context were the following: the assaults occurred exclusively in private areas $(100 \%)$, predominantly at the homes of the victims and accused offenders. In contrast, within the extrafamilial context, $17 \%$ of the cases occurred in public areas, such as streets and plazas, and 83\% occurred in private areas, predominantly at the accused offenders' homes.

In the sample we studied, with respect to the extrafamilial context, $55 \%$ of the sexual assaults occurred only once; $20 \%$, more than once; and in $25 \%$ of the cases, no information as to the number of incidents or the duration of the assaults was provided. In relation to the intrafamilial context, more than one assault was committed in $46 \%$ of the cases; $21 \%$ were reported as a single assault; and in $33 \%$, it was not possible to identify the number of incidents of sexual violence.

With respect to the intrafamilial context, more than one assault was committed in $46 \%$ of the cases; $21 \%$ were reported as a single aggression; and in $33 \%$, it was not possible to identify the number of incidents of sexual violence.

The present study revealed that the court cases exhibited a lack of information concerning the accused offenders, especially with respect to their personal backgrounds; several suits were even filed without identifying the offenders' names. In such cases, a nickname was employed. 
Information as to the accused offenders was found to be lacking predominantly in the extrafamilial context.

In the cases we analyzed, it was observed that $98 \%$ of the accused offenders were men, and $57 \%$ were over the age of 30 when the pro- ceedings commenced. Within the intrafamilial context, $76 \%$ had a spouse, in contrast with the extrafamilial context, in which $54 \%$ did not. Table 1 displays the social traits of the accused offenders and their status in the prosecutions, thus identifying the characteristics prevailing among the defendants in the cases we examined.

Table 1

Characteristics of Accused Sexual Offenders in the Intrafamilial and Extrafamilial Contexts

\begin{tabular}{ccc}
\hline & \multicolumn{2}{c}{$N=206$} \\
\cline { 3 - 3 } Variables & Intrafamilial $(n=96)$ & Extrafamilial $(n=110)$ \\
$\%$ & $\%$ \\
\hline
\end{tabular}

Age when the prosecution began

Over the age of 30

Under the age of 30

Sex

Male

Female

Education

Elementary to middle school

High school to university

Marital status

\section{Married}

Single

Children

Yes

No

Degree of kinship

Parent or stepparent

Other relatives

Non-kinship

\section{Acquaintances}

Strangers

Confessed to the crime

Yes

No

Procedural status

Imprisoned 
As per the documents we examined, most of the accused offenders that, in depositions, confessed to having had some form of sexual contact with their victims affirmed that such contact had been consensual. With respect to the educational level of intrafamilial offenders, the elementary-to-middle-school level (first grade to eighth grade) predominated ( $44 \%$ of the intrafamilial cases). In contrast, $42 \%$ of the extrafamilial cases involved offenders with an educational level between high school and university.

As to the procedural status, most of the cases were still underway in the fact-finding phase; and, in the cases in which the defendants had already been convicted by a trial court (or other lower court), the convictions were still subject to review by an appellate court. Hence, since no final judgments had yet been rendered, and due to the presumption of innocence, the persons mentioned in the court documents we analyzed were named as defendants and not as perpetrators of sexual violence. The presumption of innocence is a constitutional principle that establishes a criminal defendant's right to be presumed innocent until proven guilty and affirmed by a final judgment in the highest court of the criminal justice system. In the cases we examined, most of the defendants had been released on their own recognizance pending trial, which is a procedural reality in both contexts considered in this study. The procedural status of the accused offenders can be seen in Table 2 .

Table 3 displays the results for the estimate derived from the logistic regression model, with reference to accused child sex offenders in the intrafamilial and extrafamilial contexts.

Table 2

Procedural Status of Accused Offenders in the Intrafamilial and Extrafamilial Contexts

\begin{tabular}{lcc}
\hline & \multicolumn{2}{c}{$N=206$} \\
\cline { 2 - 3 } Status of Accused Offenders & Intrafamilial $(n=96)$ & Extrafamilial $(n=110)$ \\
\hline Absolved & 3 & 3 \\
Case dismissed & 1 & 2 \\
Convicted & 4 & 1 \\
Fugitive & 12 & 6 \\
Temporarily released & 0 & 9 \\
Released on own recognizance & 61 & 63 \\
Arrested in the act and charged & 1 & 2 \\
Pre-trial detention & 18 & 14 \\
\hline
\end{tabular}

Table 3

Logistic Regression Model for Accused Sexual Offenders

\begin{tabular}{lcc}
\hline \multicolumn{1}{c}{ Variables } & $P$-value & Odds Ratio \\
\hline Age of defendant when prosecution began & .005 & 2.949 \\
Marital status & .001 & 3.557 \\
Degree of kinship & .001 & 31.54 \\
Children & .001 & 3.631
\end{tabular}


The odds ratio (2.949) for the age variable at the time the proceedings commenced indicated that accused offenders over the age of 30 were roughly two times more likely to belong to the intrafamilial context than were thoseunder30 years of age. The odds ratio (3.557) for the marital status variable revealed that defendants with a spouse were roughly three times more likely to belong to the intrafamilial context than were those who did not have a spouse.

For the kinship variable, the odds ratio (31.54) indicated that accused offenders that were relatives of the victims were 31 times more likely to belong to the intrafamilial context than were those who were not relatives; and the odds ratio (3.631) for the offspring variable showed that defendants with children were about three times more likely to belong to the intrafamilial context than were those without children. The logistic regression model was also employed to estimate the probability of sexual violence against children and adolescents for the specified context. Table 4 displays the probability of sexual violence occurring within the intrafamilial and extrafamilial contexts when the accused offender exhibited certain characteristics.

Table 4

Probability of Incidence of Sexual Violence according to Intrafamilial or Extrafamilial Context

\begin{tabular}{|c|c|c|c|c|c|}
\hline Context & $\begin{array}{c}\text { Age when } \\
\text { prosecution began }\end{array}$ & $\begin{array}{l}\text { Marital } \\
\text { status }\end{array}$ & $\begin{array}{l}\text { Relative } \\
\text { of victim }\end{array}$ & Children & $\begin{array}{c}\text { Probability } \\
(\%)\end{array}$ \\
\hline \multirow[t]{7}{*}{ Intrafamilial } & Over 30 & Married & Yes & Yes & 95.45 \\
\hline & Over 30 & Married & Yes & No & 93.37 \\
\hline & Under 30 & Married & Yes & No & 94.69 \\
\hline & Over30 & Married & Yes & Yes & 96.37 \\
\hline & Under 30 & Single & Yes & No & 90.62 \\
\hline & Under 30 & Single & Yes & No & 88.41 \\
\hline & Under 30 & Single & Yes & Yes & 93.50 \\
\hline \multirow[t]{7}{*}{ Extrafamilial } & Over 30 & Married & No & No & 35.43 \\
\hline & Over 30 & Single & No & No & 22.91 \\
\hline & Under 30 & Single & No & No & 27.33 \\
\hline & Under 30 & Single & No & Yes & 30.66 \\
\hline & Under 30 & Single & No & Yes & 35.89 \\
\hline & Under 30 & Married & No & No & 40.98 \\
\hline & Under30 & Married & No & Yes & 50.82 \\
\hline
\end{tabular}

Note. In bold, highest probability of an accused sexual offender against children belonging to the intra or extrafamiliar context according to the variables in our logistic regression model.

As shown in Table 4, there was a $96.37 \%$ chance of sexual violence being committed against minors in the intrafamilial context when the accused offenders were over the age of 30 , were married (and had children) and were relatives of the victims. Within the extrafamilial context, the highest probability was $50.82 \%$, which was reached when the accused offenders were under the age of 30 , single with no children, and not relatives of the victims. These results do not apply in a general manner to all accused child sex offenders; they are specific to the sample we studied.

\section{Discussion}

In the present study, most of the 206 cases of sexual violence we examined involved the ex- 
trafamilial context. This distribution differs from what has been observed in prior studies conducted both around the world (Langevin \& Curnoe, 2012) and in Brazil's mid-south region (Martins \& Jorge, 2010; Pincolini \& Hutz, 2014; Serafim, Saffi, Achá, \& Barros, 2011), for such studies revealed that most cases of sexual violence occurred within the intrafamilial context. On the other hand, the results presented in the present paper corroborate earlier studies conducted in Brazil's northern and northeastern regions (Baía et al., 2015; Maia \& Barreto, 2012; Santos et al., 2015), which could suggest that such regions possess their own particular pattern of case distribution between the intra and extrafamilial contexts, with most cases purportedly occurring outside the family environment.

Although, in the present study, there was no statistically significant difference between the intrafamilial and extrafamilial contexts with respect to the percentage of accused offenders, it is currently known that when the victim and the perpetrator of sexual violence are relatives that live together, the victims are much more reluctant to report the sexual assault and such disclosure is less common (Baía et al., 2015). Within the intrafamilial context, accusations of sexual violence have been based on accidental discovery or witnesses' testimonies, the latter being the most common form of disclosure in a sample that was examined in the Brazilian state of Pará, as was shown by Baía et al. (2015).

In this sense, disclosure of intrafamilial sexual abuse takes a more complex form, which purportedly makes it more difficult to report the violence because, in such cases, other family members could also be exposed to violence. Concerning this issue, Lavoratti and Silvestre (2013) state that, in most cultures, families are organized according to a patriarchal structure, thus propagating gender- and age-based inequities. The authors further state that child sexual abuse occurring within the family environment is usually a manifestation of a generalized form of violence that assails other family members and affects their relationships, such as when mothers are also victims of physical, sexual and/ or psychological abuse and are thus discouraged from taking a stance with respect to the sexual violence committed against their children.

Another factor that should be considered in this discussion is that the incidence of, and silence toward, intrafamilial child sexual abuse could be related to the accommodation syndrome. Summit (1983) classified this syndrome into five categories, of which two (secrecy and helplessness) define basic childhood vulnerability to sexual abuse, and three (entrapment and accommodation; delayed, unconvincing disclosure; and retraction) derive from incestuous relationships already consummated. In the dynamics of the abusive relationship, the child is compelled to agree to a pact of silence as to the incestuous sexual practices, frequently by way of arguments that no one will believe the story and that, if the child chooses to reveal the secret, disastrous consequences (such as death, separation, loss of esteem and affection, and the destruction of the family) will befall the child, the perpetrator and the child's loved ones. Under such circumstances, the child feels helpless, believes that nothing can be done to stop the abuse and thus "accommodates" to the situation, resignedly accepting the violence suffered.

According to Summit (1983), such circumstances can significantly delay the disclosure or discovery of intrafamilial sexual abuse, and when this occurs, it is possible that the victims do not inspire the trust of their families or support networks, resulting in inconsistent versions or the refutation (retraction) of the abuse suffered, which makes it difficult both to hold the child sex offenders responsible and to interrupt the cycle of abuse. Accordingly, it is believed that the accommodation syndrome can be associated with the secrecy syndrome and the addiction syndrome, dynamically relating to each other. Along these lines, as stated by Furnis (1993), the secrecy would be directly related to the situation of control of the sexual offender, who - knowing that his sexual conduct triggers extreme social rejection - seeks to manifest (in relation to the victim, and in the presence of third parties) behaviors that are the opposite of sexual violence, while in the privacy of the abusive relationship, coerces, threatens or seduces the victim in order 
to ensure that the secret will be kept. The addiction syndrome is characterized by impulsive behavior in light of the possibility of the practice of sexual violence becoming a habit.

Within the extrafamilial context, nonetheless, the aforementioned structure of the relationships between the offender, the victim and the victim's family is uncommon. The victims' mothers (or other caregivers), the victims themselves and other family members frequently have neither a relationship of emotional or financial dependence with the sexual offender nor a history of victimization with respect to other types of violence, a fact that facilitates charges of sexual violence when it is identified. Furthermore, the process of reporting extrafamilial violence suffered by a victim tends to be quicker and more common than that of reporting intrafamilial violence because the victims tend to enjoy greater credibility and maternal support (Baía, Magalhães, \&Veloso, 2014).

Continuing our discussion of the results, we may say that the present study also corroborates the findings of prior studies in relation to the age and kinship variables (Lussier, Bouchard, \& Beauregard, 2011; Martins \& Jorge, 2010; Pincolini \& Hutz, 2014; Rebocho \& Gonçalves, 2012). Such studies showed that intrafamilial accused sexual offenders were older and frequently had children and spouses.

Conversely, within the extrafamilial context, most accused offenders were younger and single, exhibiting a preference for teenage victims. In the Amazon region, which is located in northern Brazil, relationships between elderly men and teenagers are commonplace, especially in rural areas, where poverty is more pronounced, and public policies and social assistance for families are scarce. For such teenagers, establishing such relationships is an alternative to poverty, exhausting household chores and domestic violence (Taylor, Lauro, Segundo, \& Greene, 2015). Nonetheless, this cultural practice contrasts with statutory rules that classify such relationships as rape of a minor, especially after Brazilian Federal Penal Code Statute No. 12015 [statutory rape] was enacted in 2009. It is thus quite common for extrafamilial accused offenders not to view themselves as perpetrators of sexual violence, justifying their conduct by pointing out that their relationship with the teenager is consensual.

Various studies (Hohendorff et al., 2014; Pincolini et al., 2012; Silva et al., 2013) display results similar to those obtained in the present study, with respect to the incidence of sexual assaults. Along these lines, we observed that, in both the intrafamilial and extrafamilial contexts, such assaults purportedly occurred chiefly at private locations, especially the homes of the victims or of the accused offenders (or of both, when they lived together). Alleged child sexual abuse in vehicles or in public or secluded areas was only observed within the extrafamilial context.

A study by Lussier et al. (2011) revealed that, within the intrafamilial context, perpetrators of sexual violence customarily have only one victim, who can be repeatedly abused. Within the context mentioned in the study, some evidence suggests that such offenders have greater potential to retard the discovery of such behavior. This contrasts with what is observed within the extrafamilial context, in which the offenders have a greater number of victims, for they generally commit only one assault per victim and have less power to obstruct the discovery of such assaults.

Concerning the procedural status of the prosecutions for sexual abuse, we observed that most of the cases were still underway, for the defendants had not yet been sentenced. In this respect, Article 5 (Item LVII) of the Brazilian Federal Constitution of 1988prevents accused sexual offenders from being considered actual perpetrators, for "No one shall be considered guilty until a final penal judgment has been rendered" (Constituição da RepúblicaFederativa do Brasil, 1988). Accordingly, as long as there is a possibility of appellate review, defendants are presumed innocent under the law. A study by Pincolini and Hutz (2014) concerning sexual offenders in southern Brazil concluded that appealing to an appellate court proved to bead vantage us for the defendants in most of the cases because, from what was observed, many con- 
victed sexual offenders ended up being released from police custody pending appeal from the trial-court judgment.

In the present study, we observed that most of the accused offenders were men in both of the contexts we examined. According to Martins and Jorge (2010), the male sex is considered predominant among perpetrators of sexual violence, and this predominant trait of the offender population reinforces the gender perspective that characterizes this type of violence. We thus believe that the incidence of sexual violence in the intrafamilial and extrafamilial contexts entails serious consequences with respect to the development of both the victims and the perpetrators of such violence.

The data collected in the present study can contribute to the development of preventive and policymaking strategies targeting the treatment of people involved in this kind of abuse, especially in northern Brazil, for, as suggested by this and other studies (Baía et al., 2015; Maia \& Barreto, 2012), the northern region exhibits certain peculiarities with respect to the distribution of sexual abuse cases in the intra and extrafamilial contexts.

In light of the data presented in this article, one more clearly perceives both the importance of proposing and implementing public policies focused on preventing such violence and the need for corrective measures based on the specific characteristics of populations like those analyzed in the present study. Above all, we believe that psychosocial monitoring of convicted child sex offenders should necessarily be conducted simultaneously with the execution of the sentence, in light of the fact that both the disclosure of the perpetrated violence and the punishment stipulated for this kind of behavior can also cause the offenders great suffering, especially because many of these men have led lives deprived of positive role models, attention and affection, thus leading to faulty personal planning and the manifestation of socially reprehensible and legally punishable behavior. Hence, if no steps are taken to treat the mental health of these subjects, enabling them to rearrange and give new meaning to their lives, then proposed poli- cies aimed at effective abuse prevention will fail because the perpetrators of the violent acts are excluded from such policies, which continue to focus exclusively on the reparation of the harm suffered by the victims and their families.

\section{Final Considerations}

Although the present study has achieved its objective, mention should still be made as to the general lack of certain information concerning the psychosocial traits of the population studied in the cases we analyzed. Such a lack was especially observed in cases involving accused offenders within the extrafamilial context.

This shortcoming may thus be considered a limitation of the present study. Brazil's scarcity of nationwide and regional surveys concerning the population we studied may have limited our discussion of the results and their comparison with those of other studies. Consequently, we believe it is necessary to conduct further research on the subject matter of our study, from both a quantitative (prevalence and characteristics) and a qualitative (life story) standpoint. Qualitative studies focusing on child sex offenders could decisively contribute both to understanding the factors that motivate sexual abuse in the intrafamilial and extrafamilial contexts and to proposing preventive and therapeutic measures.

We also recommend conducting longitudinal studies, which would facilitate an understanding of the connections between the practice of intra and extrafamilial child sexual abuse and its recurrence. The results of such studies could be employed both by the prison system and other government agencies and by nongovernmental organizations. They would invaluably contribute to taking action against sexual offenders and thus preventing the recurrence of such violence.

\section{References}

Alves, A. D. N., Santos, J. M. S., Oliveira, J. S. A., \& Ramos, R. S. (2013). Conselho tutelar e abuso sexual: Ocorrências em crianças e adolescentes. Revista de Enfermagem, 7(1), 135-142. doi:10.5205/reuol.3049-24704-1LE.0701201319 
Baía, P. A., Magalhães, C. M. C., \& Veloso, M. M. X. (2014). Caracterização do suporte materno na descoberta e revelação do abuso sexual infantil. Temas em Psicologia, 22(4), 691-700. doi:10.9788/TP2014.4-02

Baía, P. A. D., Veloso, M. M. X., Habigzang, L. F., Dell'Aglio, D. D., \& Magalhães, C. M. C. (2015). Padrões de revelação e descoberta do abuso sexual de crianças e adolescentes. Revista de Psicología, 24(1), 1-19. doi:http://dx.doi. org/10.5354/0719-0581.2015.37007

Brazilian Federal Penal Code Statute No. 12015. (2009). Retrieved from http://www.planalto. gov.br/ccivil_03/_ato2007-2010/2009/1ei/ 112015.htm

Cerqueira, D., \& Coelho., D. S. C. (2014). Estupro no Brasil: Uma radiografia segundo os dados da Saúde (Nota Técnica $\left.\mathrm{N}^{\circ} 11\right)$. Brasília, DF: Instituto de Pesquisa Econômica Aplicada. Retrieved from http://www.ipea.gov.br/portal/images/stories/PDFs/nota_tecnica/140327_notatecnicadiest11.pdf

Chaves, E., \& Costa, L. F. (2012). Estudo técnico sobre o afastamento do agressor do lar no abuso sexual: Autor, família e vítima. Psicologia: Teoria e Prática, 14(2), 102-115. Retrieved from http://editorarevistas.mackenzie.br/index.php/ ptp/article/view/4776/3682

Constituição da República Federativa do Brasil. (1988). Retrieved from http://www.planalto. gov.br/ccivil_03/constituicao/constituicao.htm

Esber, K. M. (2009). Autores de violência sexual contra crianças e adolescentes. Goiás, GO: Canone.

Furnis, T. (1993). Abuso sexual da criança: Uma abordagem multidisciplinar. Porto Alegre, RS: Artes Médicas.

Guimarães, J. A. T. L., \& Villela. W. V. (2011). Características da violência física e sexual contra crianças e adolescentes atendidos no IML de Maceió, Alagoas, Brasil. Cadernos de Saúde Pública, 27(8), 1647-1653. Retrieved from http://www.scielosp.org/pdf/csp/v27n8/19.pdf

Habigzang, L. F., Azevedo, G. A., Koller, S. H., \& Machado, P. X. (2006). Fatores de risco e de proteção na rede de atendimento a crianças e adolescentes vítimas de violência sexual. Psicologia: Reflexão e Crítica, 19(3), 379-386.

Habigzang, L. F., Koller, S. H., Azevedo, G. A., \& Machado, P. X. (2005). Abuso sexual infantil e dinâmica familiar: Aspectos observados em pro- cessos jurídicos. Psicologia: Teoria e Pesquisa, 21(3), 341-348. Retrieved from http://www.scielo.br/pdf/ptp/v21n3/a11v21n3.pdf

Hohendorff, J. V., Costa, L. S., Habigzang, L. F., \& Koller, S. H. (2014). Análise documental de casos de violência sexual contra meninos notificados em Porto Alegre. Paidéia (Ribeirão Preto), 24(58), 187-196. doi:http://dx.doi. org/10.1590/1982-43272458201406

Jesus, A. P. C., \& Moreira, R. B. R. (2015). A violência sexual contra crianças e adolescentes no Brasil: Da proteção jurídica as políticas públicas. Seminário Internacional de Demandas Sociais e Políticas Públicas na Sociedade Contemporânea. Retrieved from http://online. unisc.br/acadnet/anais/index.php/sidspp/article/ view/13166/2249

Langevin, R., \& Curnoe, S. (2012). Lifetime criminal history of sex offenders seen for psychological assessment in Five decades. International Journal of Offender Therapy and Comparative Criminology, 56(7), 997-1021. doi:10.1177/0306624X11420084

Lavoratti, C., \& Silvestre, L. P. (2013). O reflexo das relações de gênero no cotidiano da violência sexual intrafamiliar contra crianças e adolescentes. DILEMAS: Revista de Estudos de Conflito e Controle Social, 6(4), 645-674.

Lodetti, A. S. (2010). Homens encarcerados por violência sexual: Um estudo sobre enunciação e performatividade (Master's thesis). Programa de Pós-Graduação em Psicologia, Universidade Federal de Santa Catarina, Florianópolis, SC, Brasil. Retrieved from https://repositorio.ufsc. br/bitstream/handle/123456789/93981/282994. pdf? sequence $=1 \&$ isAllowed $=y$

Lussier, P., Bouchard, M., \& Beauregard, E. (2011). Patterns of criminal achievement in sexual offending: Unravelling the "successful" sex ofender. Journal of Criminal Justice,39, 433-444. doi:10.1016/j.jcrimjus.2011.08.001

Maia, A. C., \& Barreto, M. (2012). Violência contra crianças e adolescentes no Amazonas: Análise dos registros. Psicologia em Estudo, 17(2), 195-204. doi:http://dx.doi.org/10.1590/S141373722012000200003

Martins, C. B. G., \& Jorge, M. H. P. M. (2010). Abuso sexual na infância e adolescência: Perfil das vítimas e agressores em um município do sul do brasil. Texto Contexto Enfermagem, 19(2), 246255. Retrieved from http://www.scielo.br/pdf/ tce/v19n2/05.pdf 
Pincolini, A. M. F., \& Hutz, C. S. (2014). Abusadores sexuais adultos e adolescentes no sul do Brasil: Pesquisa em denúncias e sentenças judiciais. Temas em Psicologia, 22(2), 301-312. doi:10.9788/TP2014.2-03

Pincolini, A. M. F., Hutz, C. S., \& Laskoski, L. (2012). Caracterização da violência sexual a partir de denúncias e sentenças judiciais. Psicologia em Pesquisa, 6(1), 19-28. Retrieved from http://pepsic.bvsalud.org/pdf/psipesq/v6n1/ v6n1a04.pdf

Rebocho, M. F., \& Gonçalves, A. (2012). Sexual predators and prey: A comparative study of the hunting behavior of rapists and child molesters. Journal of Interpersonal Violence, 27(14), 2770-2789. doi:10.1177/0886260512438280

Santos, C. A., Costa, M. C. O., Amaral, T. R., Nascimento, C. L. N., Sobrinho, Musse, J. O., \& Costa, A. M. (2015). Agressor sexual de crianças e adolescentes: Análise de situações relacionadas à violação e vítimas. Adolescência \& Saúde, 12(3), 7-20. Retrieved from http://www.adolescenciaesaude.com/detalhe artigo.asp? $\mathrm{id}=519$

Santos, B. R., \& Ippolito, R. (2011). Guia escolar: Identificação de sinais de abuso e exploração sexual de crianças e adolescentes. Soropédica, RJ: Editora da Universidade Federal Rural do Rio de Janeiro. Retrieved from http:// portaldoprofessor.mec.gov.br/storage/materiais/0000016936.pdf

Serafim, A. P., Saffi, F., Achá, M. F. F., \& Brarros, D. M. (2011). Dados demográficos, psicológicos e comportamentais de crianças e adolescentes vítimas de abuso sexual. Revista Psiquiatria Clínica, 38(4), 143-147. Retrieved from http://www. scielo.br/pdf/rpc/v38n4/a06v38n4.pdf
Silva, M. C. M., Brito, A. M., Araújo, A. L., \& Abath, M. B. (2013). Caracterização dos casos de violência física, psicológica, sexual e negligências notificados em Recife, Pernambuco, 2012. Epidemiologia e Serviços de Saúde, 22(3), 403-412. Retrieved from http://scielo.iec.pa.gov. br/pdf/ess/v22n3/v22n3a05.pdf

Summit, R. C. (1983). The child sexual abuse accomodation syndrome. Child Abuse \& $\mathrm{Ne}$ glect, 7(2), 177-193. Retrieved from http:// www.abusewatch.net/Child\%20Sexual\%20 Abuse\%20Accommodation\%20Syndrome.pdf

Taylor, A. Y., Lauro, G., Segundo, M., \& Greene, M. E. (2015). Ela vai no meu barco. Casamento na infância e adolescência no Brasil. Resultados de pesquisa de método misto. Rio de Janeiro, RJ: Instituto Promundo \& Promundo.

Vieira, M. S., Grossi, P. K., \& Gasparotto, G. P. (2014). A violência sexual infanto-juvenil e o olhar dos profissionais da rede de enfrentamento: Notas críticas acerca do cenário do município de Porto Alegre. Seminário Internacional de Demandas Sociais e Políticas Públicas na Sociedade Contemporânea, (11). Retrieved from http://online.unisc.br/acadnet/anais/index. php/sidspp/article/view/11750/1544

(C) The Author(s), 2018. Open Access. This article is distributed under the terms of the Creative Commons Attribution 4.0 International License (http://creativecommons.org/licenses/by/4.0/), which permits unrestricted use, distribution, and reproduction in any medium, provided you give appropriate credit to the original author(s) and the source, provide a link to the Creative Commons license, and indicate if changes were made. 